\title{
C-reactive protein is differentially modulated by co-existing infections, vitamin deficiencies and maternal factors in pregnant and lactating indigenous Panamanian women
}

Doris González-Fernández ${ }^{1}$, Emérita del Carmen Pons², Delfina Rueda ${ }^{3}$, Odalis Teresa Sinisterra ${ }^{4}$, Enrique Murillo 5,6, Marilyn E. Scott ${ }^{7}$ and Kristine G. Koski ${ }^{8^{*}}$

\begin{abstract}
Background: The usefulness of C-reactive protein (CRP) as a non-specific marker of inflammation during pregnancy and lactation is unclear in impoverished populations where co-existing infections and vitamin deficiencies are common.

Methods: This cross-sectional study in Panama recruited 120 pregnant and 99 lactating Ngäbe-Buglé women from 14 communities in rural Panama. Obstetric history, indoor wood smoke exposure, fieldwork, BMI, vitamins $A, B_{12}$, D, and folic acid, and inflammation markers (CRP, neutrophi/lymphocyte ratio (NLR), plateletcrit and cytokines) were measured. Multiple regressions explored both associations of CRP with other inflammatory markers and associations of CRP and elevated CRP based on trimester-specific cut-offs with maternal factors, infections and vitamin deficiencies.

Results: CRP was higher in pregnancy $(51.4 \pm 4.7 \mathrm{nmol} / \mathrm{L})$ than lactation $(27.8 \pm 3.5 \mathrm{nmol} / \mathrm{L})$ and was elevated above trimester specific cut-offs in $21 \%$ of pregnant and $30 \%$ of lactating women. Vitamin deficiencies were common (vitamin A 29.6\%; vitamin D 68.5\%; vitamin B $1268 \%$; folic acid 25.5\%) and over 50\% of women had two or more concurrent deficiencies as well as multiple infections. Multiple regression models highlighted differences in variables associated with CRP between pregnancy and lactation. In pregnancy, CRP was positively associated with greater indoor wood smoke exposure, caries and hookworm and negatively associated with Ascaris and vaginal Lactobacillus and Bacteroides/ Gardnerella scores. Consistent with this, greater wood smoke exposure, caries as well as higher diplococcal infection score increased the odds of trimester-elevated CRP concentrations whereas longer gestational age lowered the likelihood of a trimester-elevated CRP. During lactation, folic acid deficiency was associated with higher CRP whereas parity, number of eosinophils and Mobiluncus score were associated with lower CRP. Also, a higher BMI and Trichomonas vaginalis score increased the likelihood of an elevated CRP whereas higher parity and number of eosinophils were associated with lower likelihood of an elevated CRP.

Conclusions: Infections both raise and lower CRP concentrations in pregnant and lactating mothers. Only folic acid deficiency during lactation was associated with higher CRP concentrations. Caution is required when interpreting CRP concentrations in pregnant and lactating women who have co-existing nutrient deficiencies and multiple infections.

Keywords: CRP, Intestinal parasites, Caries, Vaginal infections, Folic acid deficiency, Wood smoke, Neutrophil/lymphocyte ratio, Plateletcrit, Pregnancy, Lactation
\end{abstract}

\footnotetext{
* Correspondence: kristine.koski@mcgill.ca

${ }^{8}$ School of Dietetics and Human Nutrition and Centre for Host-Parasite

Interactions, Macdonald Campus, McGill University, 21,111 Lakeshore Road,

Ste-Anne-de-Bellevue, QC H9X 3 V9, Canada

Full list of author information is available at the end of the article
} 


\section{Multilingual abstracts}

Please see Additional file 1 for translations of the six official working languages of the United Nations.

\section{Background}

C-reactive protein (CRP) is widely used in clinical practice as a non-specific acute-phase indicator of inflammation [1], given its rapid production by the liver and release into circulation [2] and its stimulation by several cytokines including IL6, IL1 $\beta$ and TNF $\alpha$ [3]. CRP also helps the body recognize the presence and severity of infections [4-6] and is used as an indicator of low-grade inflammation in chronic infections [7, 8] and chronic diseases [9]. In addition, CRP responds to a variety of maternal factors. Multiparity $[10,11]$ and exposure to wood smoke $[12,13]$ have been associated with elevated CRP in pregnancy and/or lactation whereas recreational exercise has been shown to decrease CRP $[14,15]$. CRP normally increases during gestation [16], returning to basal concentrations shortly after delivery [17]. A recent study in a population of indigenous Australian women showed CRP concentrations differed by trimester [18]. Previously, some authors have recommended use of trimester-specific cut-offs to define elevated concentrations of CRP during pregnancy $[19,20]$ whereas other authors have tried to identify cutoffs for predicting adverse pregnancy outcomes such as gestational diabetes and choriamnionitis [21].

CRP is modulated by nutritional status and deficiencies of vitamins A [22], D [23] and folic acid [24], but several studies have reported no association of CRP with vitamin $\mathrm{B}_{12}[25,26]$. CRP reportedly is higher in obese pregnant women [27], but this association was lost by the end of pregnancy [28]. Folic acid concentration has been negatively correlated with CRP in pregnant women from Korea [24] and in a non-pregnant, non-lactating population in the US [25]. Also, serum vitamin A concentrations were negatively correlated with CRP in pregnant women from Guinea-Bissau [29] and Ethiopia [22] and in lactating women from Mali [30]. Vitamin D supplementation was reported to decrease CRP concentrations in healthy Iranian pregnant women [31] but not in African-American women in their second trimester [32]. However, a large study with pregnant women in Nepal showed no effect of multiple micronutrient supplementation on indicators of inflammation including CRP [33].

CRP is a well-known soluble pattern recognition molecule that responds to infections [34]. The higher elevation of CRP in the presence of combined viral and bacterial pneumonia [35], combined human immunodeficiency virus (HIV) and tuberculosis [36], and combined dengue and malaria [37] compared with the presence of single infections, highlights the likelihood that co-occurring chronic infections are likely to cumulatively increase concentrations of CRP. On the other hand, evidence suggests that helminth infections can lower inflammation [38].

In developing countries where biomarkers of inflammation are not always available in remote settings, CRP is a widely available and cost-effective marker of inflammation [6] that can be used alongside the neutrophil/lymphocyte ratio (NLR) and platelet indices as predictors of adverse pregnancy outcomes [39-41]. Our previous work in an indigenous population living in conditions of extreme poverty in Panama revealed not only a range of bacterial, fungal, protozoan, helminth, and ectoparasite infections among pregnant and lactating women but also synergistic and antagonistic interactions among the various pathogens [42]. Furthermore, informal conversations with physicians highlighted the challenge they faced in relying on CRP as a marker of inflammation under these conditions. This led us to investigate whether CRP may respond to mildmoderate infections and/or micronutrient deficiencies experienced by pregnant or lactating women.

Our specific objectives were (1) to record CRP concentrations in a population of indigenous pregnant and lactating women and (2) to assess which among a range of other inflammatory markers (platelets, neutrophils, cytokines), environmental factors (wood smoke, field work), infections (oral, urogenital, intestinal, skin), and micronutrient deficiencies (folate, vitamins A, $\mathrm{B}_{12}$ and D) were associated with CRP concentrations during pregnancy and lactation.

\section{Methods \\ Design}

A detailed description of the study design and methodology and inclusion/exclusion criteria was previously published [42]. Briefly, this cross sectional study included 120 pregnant women (11 first, 43 second and 66 third trimester) and 99 lactating women belonging to the Ngäbe-Buglé community in the Western rural region of Panama and was conducted between August and December 2010. Questionnaires and clinical exams were conducted, and venous blood, urine, vaginal and faecal samples were obtained.

\section{Anthropometry, obstetric history, environmental factors}

Weight and height were recorded. Body mass index (BMI) [weight/(height $)^{2}$ ] was calculated and was corrected in pregnant women by subtracting estimated fetal weight using Johnson's formula [43]. Pregnant women were classified individually as underweight, normal weight or overweight/obese according to the Pan-American Health Organization weight-for-height chart [44]. The BMI for lactating women was classified as for the general population: underweight $\left(\mathrm{BMI}<18.5 \mathrm{~kg} / \mathrm{m}^{2}\right)$, normal weight (BMI between 18.5 and $24.9 \mathrm{~kg} / \mathrm{m}^{2}$ ), overweight and obese $\left(\mathrm{BMI} \geq 25 \mathrm{~kg} / \mathrm{m}^{2}\right)$ [45]. Participants answered questions 
on obstetric history, hours of indoor wood smoke exposure and fieldwork hours per day.

\section{Reactive protein}

CRP was processed at the Central Reference Laboratory in Public Health of the Gorgas Memorial Institute for Health Studies in Panama City in duplicate using solid phase enzyme-linked immunosorbent assay (MP Biomedicals, Orangeburg, NY), with a minimum detectable concentration of $0.9 \mathrm{nmol} / \mathrm{L}$. The cut-offs for elevated CRP were set at $193.3 \mathrm{nmol} / \mathrm{L}$ and $77.1 \mathrm{nmol} / \mathrm{L}$ in the second and third trimesters, respectively [20]. During the first trimester and during lactation, the cut-off for non-pregnant women of $28.5 \mathrm{nmol} / \mathrm{L}$ was used [20].

\section{Infections and co-morbidities}

Oral, skin and urogenital infections were assessed clinically. Urine (118 pregnant and 94 lactating women), vaginal (119 pregnant and 79 lactating women) and faecal samples (120 pregnant and 23 lactating women) were analysed for infections as previously described [42]. Presence or absence of caries, scabies, asymptomatic bacteriuria/urinary tract infection (AB/UTI), Ascaris, hookworm and Trichuris were recorded and semiquantitative scores (0 to 4) of vaginal Lactobacillus, Bacteroides/Gardnerella, Mobiluncus, Trichomonas vaginalis, yeast and diplococcal infections were recorded. Bacterial vaginosis (BV) was diagnosed using the Nugent score, calculated as: Bacteroides/Gardnerella score + (4 Lactobacillus score) +(Mobiluncus score/2) [46]. HIV and gestational diabetes were ruled out; the study area was non-endemic for malaria. Mothers reported no allergic conditions or history or symptoms of chronic cardiovascular, renal or autoimmune diseases.

\section{Micronutrient concentrations}

Serum samples were analysed for folic acid and vitamin $B_{12}$ concentrations using immunoelectro-chemiluminescence on the analyser MODULAR E170 (Roche Diagnostics $\mathrm{GmBH}$, Mannheim, Germany) at the Canadian Diagnostics Laboratory, a national reference laboratory in Montreal. Folic acid deficiency was defined as $<10 \mathrm{nmol} / \mathrm{L}$ and vitamin $B_{12}$ deficiency as $<150 \mathrm{pmol} / \mathrm{L}$ [47].

Serum vitamin A was detected using high-performance liquid chromatography at the Institute of Scientific Research and High Technology Services-INDICASAT in Panama City [48]. The cut-off for vitamin A deficiency was set at $<1.05 \mu \mathrm{mol} / \mathrm{L}$ during pregnancy and lactation [49], and the cut-off for higher than normal vitamin $\mathrm{A}$ was set at $>1.5 \mu \mathrm{mol} / \mathrm{L}$ for both pregnancy [20] and lactation [50].

Serum $\mathrm{OH}$ vitamin $\mathrm{D}$ was assayed using the LIAISON, DiaSorin direct competitive chemiluminescence immunoassay (lot 125756, kit 72947). The intra-assay coefficients of variation were $1.2 \%$ and $3.3 \%$ for pregnant women and
$2.2 \%$ and $3.1 \%$ for lactating women. Respective inter-assay variabilities were $3.8 \%$ and $17.1 \%$. We used a cut-off for vitamin D deficiency of $<50 \mathrm{nmol} / \mathrm{L}$ [51].

\section{White blood cells (WBC) and platelets}

Blood samples were analysed for complete blood cell count using a BC-5500 Mindray Auto Hematology Analyzer. Data were recorded on total white blood cells, number of neutrophils, lymphocytes, eosinophils and basophils, NLR, and number of platelets (120 pregnant and 99 lactating women). Plateletcrit, mean platelet volume (MPV) and platelet distribution width (PDW) were also recorded.

Concentrations of cytokines (Interleukin (IL) 1 $\beta$, IL4, IL6, IL10, IL12, IL13, IL17, TNF $\alpha$ and INF $\gamma$ ) were analyzed via Luminex (Luminex Corp., U.S.A.) as part the Human 10plex Cytokine/Chemokine Magnetic Bead Panel (Cat. HCYTOMAG-60 K; Millipore Corporation Canada) according to manufacturer instructions at the School of Dietetics and Human Nutrition, McGill University. Minimum detection limits $(\mathrm{pg} / \mathrm{mL})$ were: $\operatorname{IL} 1 \beta=0.8$, IL $4=4.5$, IL6 $=0.9, \quad$ IL10 $=1.1, \quad$ IL12 $=0.6, \quad$ IL13 $=1.3, \quad$ IL17 $=0.7$, $\mathrm{TNF} \alpha=0.7, \mathrm{INF} \gamma=0.8$. For each essay, standards and quality controls were analysed in duplicate and quality controls were within accepted ranges.

\section{Statistical analyses}

Statistics were performed using STATA 14 (StataCorp LP, Texas, USA). CRP was not normally distributed and was $\log$ transformed unless otherwise indicated. Kolmogorov-Smirnov test compared those non-normally distributed variables (age, parity, wood smoke, BMI and interleukins) between pregnancy and lactation. Student's $t$-tests compared normally distributed vitamin D, MPV, PDW and plateletcrit, and log transformed folic acid, vitamin $B_{12}$, vitamin $A, W B C$ counts and total platelets between pregnancy and lactation. $\mathrm{Chi}^{2}$ analysis compared the frequency of vitamin deficiencies between pregnancy and lactation. T-tests were also used to compare log CRP between binary classifications of exposure (yes/no) to wood smoke and fieldwork, presence/absence of specific infectious and micronutrient deficiencies in both pregnant and lactating women. One-way ANOVA compared log CRP by trimesters, by age $(<19$ yrs, $19-$ 35 yrs and $>35$ yrs), by parity (1,1 -4 and $\geq 5$ pregnancies) and by BMI (underweight, normal weight, overweight) classifications. Spearman correlations were used to identify correlations of non-transformed CRP with WBC, platelet indices and cytokines and Kruskal Wallis test to compare pregnant and lactating women with $0,1,2$, or 3 concurrent micronutrient deficiencies. $P$-values $<0.05$ were considered significant. A multiple linear regression analysis associated inflammatory markers (WBC, platelet and cytokines) with log-transformed CRP in pregnancy and in lactation. 
Separate stepwise multiple linear regression models for log CRP and multiple logistic regression models for elevated CRP were done for both pregnant and lactating women, controlling for parity and BMI as well as gestational age of pregnant women and weeks post-partum for lactating women. In the final linear regression model for $\log$ CRP and logistic regression model for elevated CRP, we included environmental factors, infections with a prevalence $>10 \%$, and vitamin deficiencies. The following variables were entered: hours of wood smoke exposure and fieldwork; presence of caries, semi-quantitative scores of vaginal Lactobacillus, Bacteroides/Gardnerella, Mobiluncus, $T$. vaginalis, yeast and diplococcal infections and deficiencies of folic acid, vitamins $\mathrm{B}_{12}$, A and D. In pregnancy, presence of Ascaris, hookworm and Trichuris was also included. In lactation, eosinophil count was included.

All models were tested for collinearity using variance inflation factors (VIF) and the stability of the regression coefficients was assessed using the condition number. Models were considered suitable if $\mathrm{VIF}<10$ and condition number $<30$. AB/UTI and scabies were excluded from models of lactating women due to collinearity.

\section{Results}

\section{Maternal characteristics and infections}

The population was characterized by high rates of adolescent pregnancy (26.9\%), grand-multiparity (27.4\%), and indoor wood smoke exposure (94.5\%). The majority of women $(62.1 \%)$ were of normal weight, $6.8 \%$ were underweight and $31 \%$ of women were overweight. About half of the women (46.1\%) worked in the field. Almost all women (97\%) were infected with at least one vaginal pathogen. Other common infections included hookworm (55.2\%), AB/UTI (45.7\%), Ascaris (30\%), caries (19.6\%), scabies (15.5\%) and Trichuris (11.9\%), as reported previously [42].

\section{Vitamins}

Deficiencies of vitamin $\mathrm{B}_{12}$ (85.8\% in pregnancy; $46 \%$ in lactation, $X^{2}$ test $\left.P<0.0001\right)$ and vitamin $\mathrm{A}(38.6 \%$ in pregnancy; $18.5 \%$ in lactation, $\chi^{2}$ test $P=0.001$ ) were more common in pregnancy. Neither deficiency of vitamin $\mathrm{D}\left(68.3 \%\right.$ in pregnancy; $68.7 \%$ in lactation, $X^{2}$ test $P=0.95)$ nor folic acid $(31.3 \%$ in pregnancy; $20.8 \%$ in lactation, $P=0.07$ ) differed between pregnancy and lactation. Concurrent micronutrient deficiencies were more often found in pregnant than in lactating women (Kruskal-Wallis test: $P=0.0003$ ) (Fig. 1). Two concurrent deficiencies were found in $48 \%$ of pregnant and $43.3 \%$ of lactating women, 3 concurrent deficiencies occurred in $23.5 \%$ of pregnant and $11.3 \%$ lactating women, and 4 concurrent deficiencies were found in $7.5 \%$ of pregnant and $3.1 \%$ of lactating women. T-test comparisons of vitamin concentrations revealed that pregnant women had higher folic acid concentrations but lactating women had higher concentrations of vitamins $A$ and $B_{12}$ (Table 1).

\section{Inflammation markers}

The numbers of WBC and neutrophils, the NLR, and PDW were higher in pregnant women, but numbers of lymphocytes, eosinophils, basophils, platelets and plateletcrit were higher in lactating women (Table 1). Concentrations of all measured cytokines (IL1 $\beta$, IL4, IL6, IL10, IL12, IL13, IL17, INF $\gamma$, TNF $\alpha$ ) were higher in pregnant than in lactating women (Table 1).

\section{CRP}

Mean CRP concentration was higher in pregnancy than lactation (Table 1), but did not differ between first (35.1 \pm $8.4 \mathrm{nmol} / \mathrm{L}$; median 31.4; interquartile range (IQR) 51.4), second $(58.4 \pm 9.7 \mathrm{nmol} / \mathrm{L}$; median 32.4; IQR 57.1) and third (50.0 $\pm 5.7 \mathrm{nmol} / \mathrm{L}$; median 37.6; IQR 62.8) trimesters. Based on trimester-specific cut-offs, elevated CRP occurred in $63.6 \%, 7.0 \%$ and $22.7 \%$ of first, second and third trimester women, respectively, and in $30 \%$ of lactating mothers (Fig. 2).

CRP did not differ among women according to age, parity or BMI classifications. CRP concentrations were compared between binary categories for a variety of maternal variables (Table 2). In pregnancy, CRP concentrations were higher in women with caries (Table 2) and lower in those with Ascaris (Table 2). During lactation, CRP concentrations were higher in women with above normal vitamin A $(>1.5 \mu \mathrm{mol} / \mathrm{L})$ and lower in grand-multiparous women and those with caries (Table 2).

In pregnancy, CRP was positively correlated with NLR $\left(r_{\mathrm{s}}=0.24, P=0.008\right)$, platelet count $\left(r_{\mathrm{s}}=0.20, P=0.032\right)$, plateletcrit $\left(r_{\mathrm{s}}=0.23, P=0.012\right)$, IL6 $\left(r_{\mathrm{s}}=0.23, P=0.011\right)$, IL10 $\left(r_{\mathrm{s}}=0.25, P=0.005\right), \quad$ IL12 $\left(r_{\mathrm{s}}=0.28, P=0.002\right)$, IL13 $\left(r_{\mathrm{s}}=0.25, \mathrm{P}=0.005\right)$ and TNF $\alpha\left(r_{\mathrm{s}}=0.22, P=0.015\right)$. In lactation, CRP was positively correlated with numbers of neutrophils $\left(r_{\mathrm{s}}=0.30, P=0.002\right)$, NLR $\left(r_{\mathrm{s}}=0.29\right.$, $P=0.003)$, platelet count $\left(r_{\mathrm{s}}=0.40, \quad P<0.0001\right)$, plateletcrit $\left(r_{\mathrm{s}}=0.34, P=0.0006\right)$ and IL4 $\left(r_{\mathrm{s}}=0.20\right.$, $P=0.042)$, and negatively correlated with number of eosinophils $\left(r_{\mathrm{s}}=-0.25, P=0.010\right)$ and MPV $\left(r_{\mathrm{s}}=-0.27\right.$, $P=0.006)$.

To determine whether CRP was associated with other markers of inflammation and to confirm significant correlations, multiple regression analyses controlling for gestational age, parity and BMI during pregnancy revealed a positive association of log CRP with NLR and plateletcrit and accounted for $14.5 \%$ of the variability in CRP (Table 3 ). During lactation, log CRP was also positively associated with plateletcrit and negatively associated with number of eosinophils when controlling for weeks postpartum, parity and BMI and the model explained $27.5 \%$ of variability in 


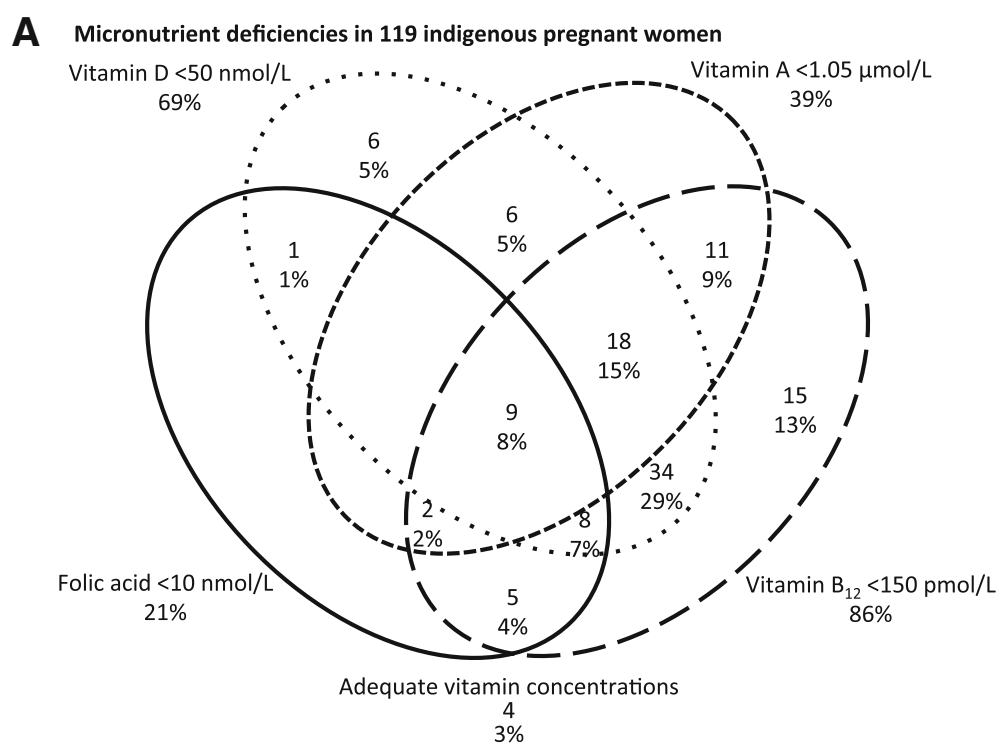

B Micronutrient deficiencies in 97 indigenous lactating women

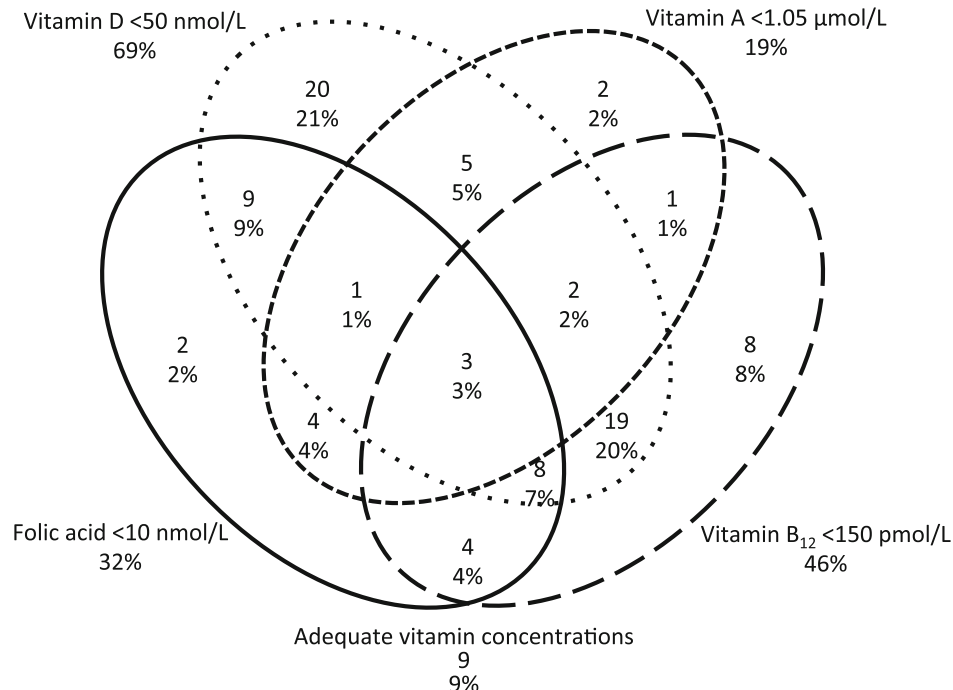

Fig. 1 Venn diagram of co-existing micronutrient deficiencies in a pregnant women, and $\mathbf{b}$ lactating women. Legend: In both pregnancy and lactation, ovals drawn with a continuous line represent women with folic acid $<10 \mathrm{nmol} / \mathrm{L}$, ovals with large-dashed lines represent women with vitamin $B_{12}<150 \mathrm{pmol} / \mathrm{L}$, medium-dashed lines circumscribe women with vitamin $A<1.05 \mu \mathrm{mol} / \mathrm{L}$ and dots denote women with vitamin $\mathrm{D}<50 \mathrm{nmol} / \mathrm{L}$. Only $3 \%$ of pregnant and $9 \%$ of lactating women had adequate vitamin concentrations

CRP. No cytokines emerged in either model (Table 3).

\section{Role of maternal factors, infections and vitamin deficiencies as determinants of CRP}

During pregnancy, our final multiple linear regression model explained $18.9 \%$ of variation in log CRP (Table 4). Wood smoke, presence of caries and hookworm were positively associated with CRP; presence of Ascaris, and scores for vaginal Lactobacillus and Bacteroides/ Gardnerella were negatively associated with CRP. Using trimester specific cut-offs for elevated CRP (Table 4), our multiple logistic regression model showed that presence of caries, higher diplococcal infection score and greater indoor wood smoke exposure were associated with higher likelihood of elevated CRP, and higher gestational age was associated with a lower likelihood of elevated CRP. The Pseudo $\mathrm{R}^{2}$ was 0.243 .

During lactation, our composite multiple linear regression model captured $24.4 \%$ of the variability in log CRP. Folic acid deficiency was positively associated with CRP; the number of eosinophils, the Mobiluncus score and parity were negatively associated with CRP (Table 5). Our 
Table 1 Comparisons between impoverished pregnant and lactating women in rural Panama ${ }^{1}$

\begin{tabular}{|c|c|c|c|c|}
\hline & Pregnancy & Lactation & Pregnancy & Lactation \\
\hline & Mean $\pm S E$ & Mean $\pm S E$ & Median $(\mathrm{IQR})^{2}$ & Median $(\mathrm{IQR})^{2}$ \\
\hline \multicolumn{5}{|l|}{ Maternal Characteristics } \\
\hline Age, y & $24.8 \pm 0.6$ & $25 \pm 0.7$ & $24(11)$ & $23(10)$ \\
\hline Parity, \# & $3.4 \pm 0.2$ & $3.5 \pm 0.2$ & $3(4)$ & $3(3)$ \\
\hline Wood smoke, h/d & $2.5 \pm 0.1$ & $2.3 \pm 0.1$ & $2(1)$ & $2(1)$ \\
\hline Fieldwork, h/d & $4.5 \pm 0.3$ & $4.7 \pm 0.3$ & $4(3.5)$ & $4(4)$ \\
\hline $\mathrm{BMI}\left(\mathrm{kg} / \mathrm{m}^{2}\right)$ & $25.1 \pm 0.3$ & $25.5 \pm 0.3$ & $24.7(4.6)$ & $25.1(4.9)$ \\
\hline \multicolumn{5}{|l|}{ Nutritional Status Indicators } \\
\hline Folic acid, nmol/L & $16.0 \pm 0.7^{\mathrm{a}^{*}}$ & $13.5 \pm 0.6^{b}$ & $14(8.1)$ & $11.9(7.3)$ \\
\hline Vitamin $B_{12}, \mathrm{pmol} / \mathrm{L}$ & $111.1 \pm 4.3^{b}$ & $170.2 \pm 7.2^{\mathrm{a}^{*}}$ & $100(48)$ & $153(62)$ \\
\hline Vitamin A, $\mu \mathrm{mol} / \mathrm{L}$ & $1.20 \pm 0.03^{b}$ & $1.47 \pm 0.04^{\mathrm{a}^{* *}}$ & $1.17(0.46)$ & $1.42(0.66)$ \\
\hline Vitamin $\mathrm{D}, \mathrm{nmol} / \mathrm{L}$ & $43.1 \pm 1.4$ & $43.0 \pm 1.4$ & $39.7(22.0)$ & $42.2(19.8)$ \\
\hline \multicolumn{5}{|l|}{ White Blood Cells (WBC) } \\
\hline Total WBC $\times 10^{9} / \mathrm{L}$ & $8.92 \pm 0.21^{\mathrm{a}^{*}}$ & $8.21 \pm 0.18^{b}$ & $8.6(2.8)$ & $7.8(2.4)$ \\
\hline Neutrophils $\times 10^{9} / \mathrm{L}$ & $6.07 \pm 0.20^{\mathrm{a}^{* *}}$ & $4.55 \pm 0.15^{b}$ & $5.9(2.3)$ & $4.1(1.7)$ \\
\hline Lymphocytes $\times 10^{9} / \mathrm{L}$ & $2.01 \pm 0.04^{b}$ & $2.45 \pm 0.06^{\mathrm{a}^{* *}}$ & $1.9(0.6)$ & $2.3(0.8)$ \\
\hline Monocytes $\times 10^{9} / \mathrm{L}$ & $0.39 \pm 0.01$ & $0.38 \pm 0.01$ & $0.37(0.14)$ & $0.36(0.12)$ \\
\hline Eosinophils $\times 10^{9} / \mathrm{L}$ & $0.39 \pm 0.02^{b}$ & $0.78 \pm 0.06^{\mathrm{a}^{* *}}$ & $0.36(0.29)$ & $0.61(0.57)$ \\
\hline Basophils $\times 10^{9} / \mathrm{L}$ & $0.03 \pm 0.00^{b}$ & $0.05 \pm 0.00^{\mathrm{a}^{* *}}$ & $0.03(0.02)$ & $0.04(0.03)$ \\
\hline Neutrophil/lymphocyte ratio (NLR) & $3.15 \pm 0.14^{\mathrm{a}^{* *}}$ & $1.96 \pm 0.08^{b}$ & $2.9(1.1)$ & $1.7(0.9)$ \\
\hline \multicolumn{5}{|l|}{ Platelets } \\
\hline Total platelets $\times 10^{9} / \mathrm{L}$ & $262.8 \pm 5.6^{b}$ & $323.4 \pm 1.0^{\mathrm{a}^{* *}}$ & $262(82.5)$ & $306(113)$ \\
\hline$M P V, f L$ & $8.9 \pm 0.1$ & $8.8 \pm 0.10$ & $8.8(1.2)$ & $8.7(1.4)$ \\
\hline PDW & $15.9 \pm 0.03^{\mathrm{a}^{* *}}$ & $15.6 \pm 0.04^{b}$ & $15.9(0.6)$ & $15.6(0.5)$ \\
\hline Plateletcrit, \% & $23.5 \pm 0.4^{b}$ & $28.3 \pm 0.71^{\mathrm{a}^{* *}}$ & $23(7)$ & $26.9(8)$ \\
\hline \multicolumn{5}{|l|}{ Cytokines, pg/mL } \\
\hline IL1-B & $4.9 \pm 0.5^{\mathrm{a}^{* *}}$ & $1.5 \pm 0.4^{b}$ & $1.72(7.7)$ & $0.02(1.3)$ \\
\hline IL4 & $19.7 \pm 2.5^{5^{* *}}$ & $3.9 \pm 0.6^{b}$ & $9.1(23.4)$ & $2.1(4.0)$ \\
\hline IL6 & $8.8 \pm 1.1^{\mathrm{a}^{* *}}$ & $4.9 \pm 1.2^{\mathrm{b}}$ & $1.6(11.8)$ & $1.6(0)$ \\
\hline IL10 & $3.9 \pm 0.6^{\mathrm{a}^{* *}}$ & $1.3 \pm 0.3^{b}$ & $1.2(4.8)$ & $0.3(1.2)$ \\
\hline IL12 & $15.6 \pm 3.1^{\mathrm{a}^{*}}$ & $4.6 \pm 0.8^{b}$ & $1.5(21.5)$ & $1.3(5.7)$ \\
\hline IL13 & $4.4 \pm 0.6^{\mathrm{a}^{* *}}$ & $1.2 \pm 0.2^{b}$ & $1.6(7.4)$ & $0.9(0.9)$ \\
\hline IL17 & $6.5 \pm 0.7^{\mathrm{a}^{* *}}$ & $3.5 \pm 1.2^{b}$ & $2.3(10.9)$ & $0.8(1.2)$ \\
\hline INF- $\gamma$ & $9.0 \pm 1.0^{\mathrm{a}^{* *}}$ & $7.6 \pm 2.6^{b}$ & $3.6(13.2)$ & $1.6(3.4)$ \\
\hline TNF-a & $7.5 \pm 0.7^{\mathrm{a}^{*}}$ & $6.0 \pm 0.5^{b}$ & $6.5(12.4)$ & $4.4(6.9)$ \\
\hline CRP (nmol/L) & $51.6 \pm 4.7^{\mathrm{a}^{* *}}$ & $27.6 \pm 3.5^{b}$ & $32.8(58.1)$ & $12.3(30.4)$ \\
\hline
\end{tabular}

${ }^{1}$ Values are means $\pm S E$ or IQR, $n=120$ for pregnancy with the exception of wood smoke (114), fieldwork (60), vitamin A and cytokines (119), MPV, PDW and plateletcrit (115). For lactation, $n=99$ with the exception of wood smoke (93), fieldwork (41), vitamin A and MPV, PDW and plateletcrit (97). Means with different letter superscripts are significantly different at ${ }^{*} P<0.05$ and ${ }^{* *} P<0.0001$

${ }^{2} \mathrm{QQR}=\mathrm{Q} 3-\mathrm{Q} 1$ value

multiple logistic regression model for elevated CRP in lactation had a Pseudo $\mathrm{R}^{2}$ of 0.243 (Table 5). Higher T. vaginalis score and BMI were associated with a higher likelihood of elevated CRP, and a higher number of eosinophils and parity were associated with lower likelihood of elevated CRP.

\section{Discussion}

Several key findings emerged from this study. First, our results differentiated between those infections that were associated with higher CRP and those associated with lower CRP. During pregnancy, dental caries, hookworm and vaginal diplococcal infection were associated with higher CRP 


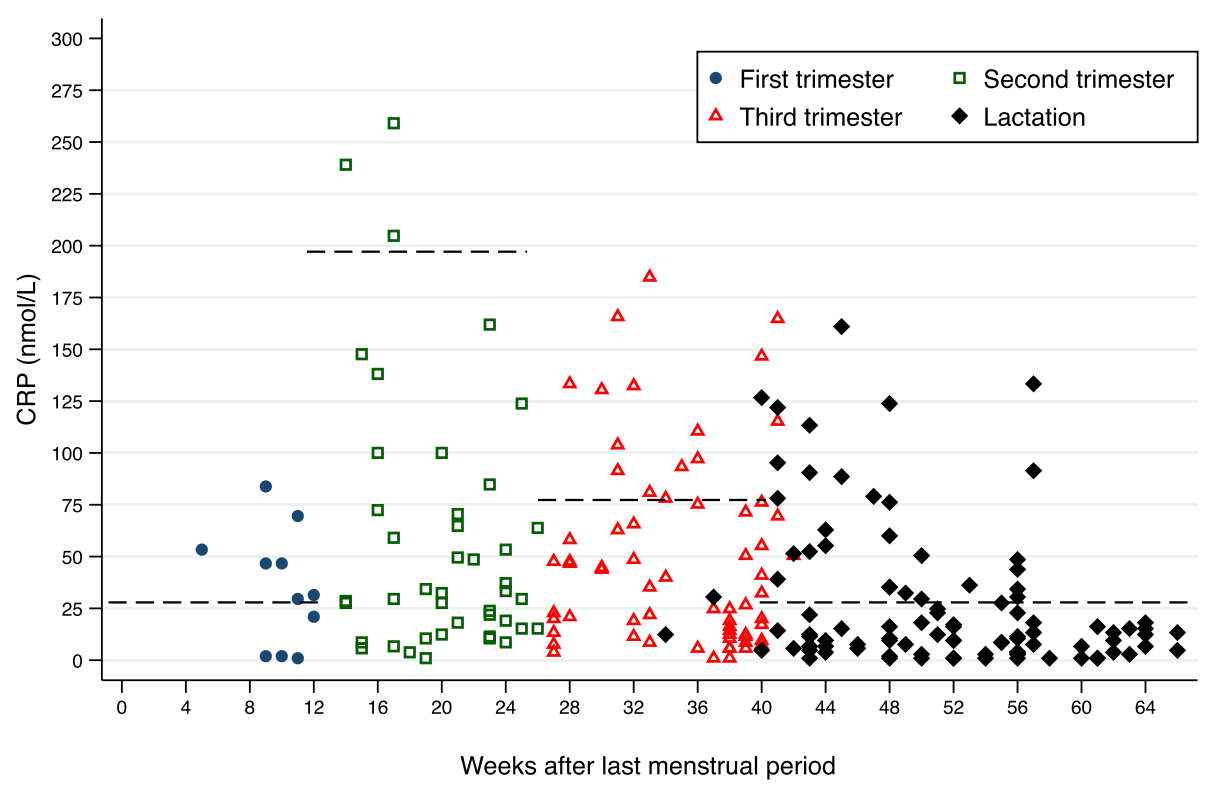

Fig. 2 Mean CRP ( $\mathrm{nmol} / \mathrm{L}$ ) by weeks after last menstrual period in indigenous pregnant and lactating women. Legend: Circles, squares and triangles indicate pregnant women in their first, second and third trimesters, respectively. Diamond markers indicate lactating women. Dashed horizontal lines denote cut offs for elevated CRP (first trimester and lactation = $28.5 \mathrm{nmol} / \mathrm{L}$; second trimester $=193.3 \mathrm{nmol} / \mathrm{L}$; third trimester $=77.1 \mathrm{nmol} / \mathrm{L})[20]$

or increased the odds of trimester-specific elevated CRP whereas Ascaris, Lactobacillus and Bacteroides/Gardnerella were negatively associated with an elevated CRP. During lactation, vaginal trichomoniasis was associated with an elevated CRP whereas vaginal Mobiluncus and eosinophil counts were associated with lower CRP and/or lower odds of an elevated CRP. Second, although deficiencies of vitamins $\mathrm{A}, \mathrm{B}_{12}$, D and folic acid were common, only folic acid deficiency was associated with higher CRP in lactating women. Third, higher daily indoor wood smoke exposure was positively associated with CRP and increased the odds of elevated CRP in pregnancy. Together, these results show that, after correcting for the normal elevation of CRP during pregnancy, the systemic CRP concentration is influenced by the mix of diverse infections, folic acid deficiency and maternal wood smoke exposure in this vulnerable population.

Our finding that CRP was positively associated with NLR and plateletcrit is consistent with their usefulness as markers of inflammation [2, 52]. NLR is thought to be an early marker of bacteremia given its positive association with CRP [53], and NLR has also been associated with placental inflammation when $\mathrm{NLR} \geq 6.48$ and $\mathrm{CRP} \geq 71 \mathrm{nmol} / \mathrm{L}$ [54]. Activation of platelets occurs in response to inflammatory stimuli [55], and activated platelets are enlarged resulting in higher plateletcrit [56]. Our negative association of eosinophils with CRP during lactation is consistent with the production of Th2 cytokines, particularly IL4, by eosinophils [57]; both Th2 and IL4 are required for protection against intestinal nematodes and for suppression of a Th1 pro-inflammatory cytokine response [58].

Although CRP was positively correlated with four cytokines during pregnancy and three during lactation, cytokines did not emerge in the multiple regression model. We interpret this to mean that CRP was a more specific marker of inflammation than cytokines in this population. Thus, we suggest that plateletcrit and NLR that have been useful for the diagnosis of obstetric pathologies in tertiary care $[39,59]$ would be alternatives to evaluate inflammation in pregnant and lactating women in settings where a complete blood count, but not CRP measurement, is possible.

Among the four vitamin deficiencies detected in this population, only folic acid deficiency was associated with higher CRP and only in lactating women. This is consistent with the observation that folate intake was protective against elevation of CRP above $28.5 \mathrm{nmol} / \mathrm{L}$ in lactating women from Kenya [60] and that young Vietnamese women with higher folic acid intake had lower CRP [61]. The absence of a relationship between folic acid deficiency and CRP during pregnancy is most likely because women in our study were receiving folic acid supplementation during pregnancy. These findings suggest that there may be a need to extend folate supplementation beyond the 3 months post-partum established in the national protocol.

Among the many infections detected [42], several were associated with higher CRP and/or a higher likelihood of an elevated CRP. In pregnancy, the finding that caries was 
Table 2 CRP concentrations ( $\mathrm{nmol} / \mathrm{L}$ ) in the presence and absence of maternal conditions in pregnancy and lactation ${ }^{1}$

\begin{tabular}{|c|c|c|c|c|}
\hline \multirow[b]{2}{*}{ Condition } & \multicolumn{2}{|l|}{ PREGNANCY } & \multicolumn{2}{|l|}{ LACTATION } \\
\hline & Yes & No & Yes & No \\
\hline \multicolumn{5}{|l|}{ Environmental hazards } \\
\hline Wood smoke & $\begin{array}{l}52.2 \pm 4.9 \\
(n=114)\end{array}$ & $\begin{array}{l}41.7 \pm 19.8 \\
(n=6)\end{array}$ & $\begin{array}{l}28.0 \pm 3.7 \\
(n=93)\end{array}$ & $\begin{array}{l}24.4 \pm 8.4 \\
(n=6)\end{array}$ \\
\hline Fieldwork & $\begin{array}{l}52.3 \pm 7.5 \\
(n=60)\end{array}$ & $\begin{array}{l}51.0 \pm 5.9 \\
(n=60)\end{array}$ & $\begin{array}{l}24.0 \pm 4.7 \\
(n=41)\end{array}$ & $\begin{array}{l}30.4 \pm 5.0 \\
(n=58)\end{array}$ \\
\hline \multicolumn{5}{|l|}{ Micronutrient status } \\
\hline Folic acid $<10 \mathrm{nmol} / \mathrm{L}$ & $\begin{array}{l}61.1 \pm 11.6 \\
(n=25)\end{array}$ & $\begin{array}{l}49.2 \pm 5.1 \\
(n=95)\end{array}$ & $\begin{array}{l}30.1 \pm 6.7 \\
(n=31)\end{array}$ & $\begin{array}{l}26.7 \pm 4.2 \\
(n=68)\end{array}$ \\
\hline Vitamin $\mathrm{B}_{12}<150 \mathrm{pmol} / \mathrm{L}$ & $\begin{array}{l}48.8 \pm 4.9 \\
(n=103)\end{array}$ & $\begin{array}{l}68.7 \pm 15.5 \\
(n=17)\end{array}$ & $\begin{array}{l}24.6 \pm 4.5 \\
(n=46)\end{array}$ & $\begin{array}{l}30.5 \pm 5.4 \\
(n=53)\end{array}$ \\
\hline Vitamin $A<1.05 \mu \mathrm{mol} / \mathrm{L}$ & $\begin{array}{l}59.5 \pm 8.9 \\
(n=46)\end{array}$ & $\begin{array}{l}47.1 \pm 5.3 \\
(n=73)\end{array}$ & $\begin{array}{l}30.2 \pm 11.7 \\
(n=18)\end{array}$ & $\begin{array}{l}27.3 \pm 3.6 \\
(n=79)\end{array}$ \\
\hline Vitamin $A>1.5 \mu \mathrm{mol} / \mathrm{L}$ & $\begin{array}{l}35.6 \pm 6.5 \\
(n=22)\end{array}$ & $\begin{array}{l}55.2 \pm 5.5 \\
(n=98)\end{array}$ & $\begin{array}{l}30.6 \pm 5.5^{\mathrm{a}} \\
(n=39)\end{array}$ & $\begin{array}{l}26.0 \pm 4.8^{b} \\
(n=58)\end{array}$ \\
\hline Vitamin $\mathrm{D}<50 \mathrm{nmol} / \mathrm{L}$ & $\begin{array}{l}54.2 \pm 5.8 \\
(n=82)\end{array}$ & $\begin{array}{l}46.1 \pm 8.2 \\
(n=38)\end{array}$ & $\begin{array}{l}25.7 \pm 3.9 \\
(n=68)\end{array}$ & $\begin{array}{l}32.3 \pm 7.5 \\
(n=31)\end{array}$ \\
\hline \multicolumn{5}{|l|}{ Clinically detected Infections } \\
\hline Caries & $\begin{array}{l}74.0 \pm 12.2^{\mathrm{a}} \\
(n=25)\end{array}$ & $\begin{array}{l}45.8 \pm 4.9^{b} \\
(n=95)\end{array}$ & $\begin{array}{l}21.4 \pm 8.3^{b} \\
(n=18)\end{array}$ & $\begin{array}{l}29.2 \pm 3.9^{\mathrm{a}} \\
(n=81)\end{array}$ \\
\hline Scabies & $\begin{array}{l}53.1 \pm 11.8 \\
(n=26)\end{array}$ & $\begin{array}{l}51.2 \pm 5.1 \\
(n=94)\end{array}$ & $\begin{array}{l}25.8 \pm 9.5 \\
(n=8)\end{array}$ & $\begin{array}{l}27.9 \pm 3.8 \\
(n=91)\end{array}$ \\
\hline \multicolumn{5}{|l|}{ Laboratory detected infections } \\
\hline $\mathrm{AB} / \mathrm{UTI}$ & $\begin{array}{l}53.5 \pm 7.1 \\
(n=63)\end{array}$ & $\begin{array}{l}47.1 \pm 6.1 \\
(n=55)\end{array}$ & $\begin{array}{l}26.0 \pm 6.4 \\
(n=34)\end{array}$ & $\begin{array}{l}30.0 \pm 4.5 \\
(n=60)\end{array}$ \\
\hline Bacterial vaginosis & $\begin{array}{l}52.5 \pm 6.0 \\
(n=73)\end{array}$ & $\begin{array}{l}50.8+7.9 \\
(n=46)\end{array}$ & $\begin{array}{l}21.7 \pm 4.3 \\
(n=50)\end{array}$ & $\begin{array}{l}22.8 \pm 5.6 \\
(n=29)\end{array}$ \\
\hline Lactobacillus & $\begin{array}{l}48.8 \pm 6.7 \\
(n=59)\end{array}$ & $\begin{array}{l}54.8 \pm 6.8 \\
(n=60)\end{array}$ & $\begin{array}{l}22.2 \pm 6.9 \\
(n=21)\end{array}$ & $\begin{array}{l}22.0 \pm 3.9 \\
(n=58)\end{array}$ \\
\hline Bacteroides/Gardnerella & $\begin{array}{l}51.5 \pm 4.8 \\
(n=114)\end{array}$ & $\begin{array}{l}59.4 \pm 29.6 \\
(n=5)\end{array}$ & $\begin{array}{l}22.5 \pm 3.5 \\
(n=77)\end{array}$ & $\begin{array}{l}5.2 \pm 4.3 \\
(n=2)\end{array}$ \\
\hline Mobiluncus & $\begin{array}{l}48.8 \pm 4.9 \\
(n=95)\end{array}$ & $\begin{array}{l}63.9 \pm 13.7 \\
(n=24)\end{array}$ & $\begin{array}{l}20.6 \pm 3.4 \\
(n=69)\end{array}$ & $\begin{array}{l}31.4 \pm 13.4 \\
(n=10)\end{array}$ \\
\hline Vaginal Trichomoniasis & $\begin{array}{l}52.8 \pm 5.8 \\
(n=88)\end{array}$ & $\begin{array}{l}49.1 \pm 8.0 \\
(n=31)\end{array}$ & $\begin{array}{l}23.0 \pm 3.7 \\
(n=72)\end{array}$ & $\begin{array}{l}12.0 \pm 3.7 \\
(n=7)\end{array}$ \\
\hline Vaginal yeast infection & $\begin{array}{l}47.2 \pm 10.3 \\
(n=33)\end{array}$ & $\begin{array}{l}53.3 \pm 5.2 \\
(n=87)\end{array}$ & $\begin{array}{l}16.0 \pm 5.7 \\
(n=9)\end{array}$ & $\begin{array}{l}22.9 \pm 3.8 \\
(n=70)\end{array}$ \\
\hline Vaginal Diplococcal infection & $\begin{array}{l}64.4 \pm 14.3 \\
(n=24)\end{array}$ & $\begin{array}{l}48.6 \pm 4.7 \\
(n=95)\end{array}$ & $\begin{array}{l}18.1 \pm 4.5 \\
(n=25)\end{array}$ & $\begin{array}{l}23.9 \pm 4.5 \\
(n=54)\end{array}$ \\
\hline Ascaris & $\begin{array}{l}44.0 \pm 8.1^{b} \\
(n=39)\end{array}$ & $\begin{array}{l}55.3 \pm 5.8^{\mathrm{a}} \\
(n=81)\end{array}$ & $\begin{array}{l}35.0 \pm 11.9 \\
(n=4)\end{array}$ & $\begin{array}{l}35.9 \pm 10.4 \\
(n=19)\end{array}$ \\
\hline Hookworm & $\begin{array}{l}55.9 \pm 6.5 \\
(n=68)\end{array}$ & $\begin{array}{l}46.1 \pm 6.8 \\
(n=52)\end{array}$ & $\begin{array}{l}34.8 \pm 14.7 \\
(n=11)\end{array}$ & $\begin{array}{l}36.5 \pm 10.6 \\
(n=12)\end{array}$ \\
\hline Trichuris & $\begin{array}{l}33.3 \pm 10.9 \\
(n=15)\end{array}$ & $\begin{array}{l}54.3 \pm 5.1 \\
(n=105)\end{array}$ & $\begin{array}{l}49.4 \pm 27.3 \\
(n=2)\end{array}$ & $\begin{array}{l}34.4 \pm 9.4 \\
(n=21)\end{array}$ \\
\hline
\end{tabular}

${ }^{1}$ Values are means $\pm S E$; different letter superscripts are significantly different at $P<0.05$

associated with higher CRP is consistent with reports showing that periodontal disease is associated with elevated CRP in pregnancy [62] and correlated with CRP [63]. Furthermore, aggressive vaginal microorganisms such as Diplococcus and T. vaginalis were found to induce a systemic inflammatory response. To our knowledge this is the first report of diplococcal infection being associated with higher CRP in pregnancy. Also, the positive association detected between trichomoniasis and CRP in lactation extends the findings of a systemic inflammatory response measured through CRP and granulocytemacrophage colony-stimulating factor found in pregnant 
Table 3 Multiple regression of Log CRP with indicators of inflammation in pregnant and lactating women

\begin{tabular}{|c|c|c|c|}
\hline$\overline{\mathrm{CRP}}(\mathrm{nmol} / \mathrm{L})$ in pregnant women ${ }^{1}$ & Coefficient $\pm S E$ & $P$ & Overall Model \\
\hline $\mathrm{BMI}, \mathrm{kg} / \mathrm{m}^{2}$ & $-0.06 \pm 0.04$ & 0.039 & \multirow{6}{*}{$\begin{array}{l}n=114 \\
F_{5,108}=4.85 \\
P=0.0005 \\
\text { Adj. } R^{2}=0.145 \\
V I F=1.18\end{array}$} \\
\hline Neutrophil/lymphocyte ratio & $0.14 \pm 0.07$ & 0.041 & \\
\hline Plateletcrit, \% & $0.06 \pm 0.02$ & 0.024 & \\
\hline IL6, pg/mL & $0.01 \pm 0.009$ & 0.122 & \\
\hline IL13, pg/mL & $0.02 \pm 0.01$ & 0.142 & \\
\hline Constant & $2.83 \pm 0.94$ & 0.003 & \\
\hline CRP (nmol/L) in lactating women ${ }^{2}$ & Coefficient $\pm S E$ & P & \multirow{8}{*}{$\begin{array}{l}\text { Overall Model } \\
n=97 \\
F_{6,90}=7.09 \\
P<0.0001 \\
\text { Adj. } R^{2}=0.275 \\
\text { VIF }=1.12\end{array}$} \\
\hline Parity & $-0.12 \pm 0.05$ & 0.026 & \\
\hline $\mathrm{BMI}, \mathrm{kg} / \mathrm{m}^{2}$ & $0.06 \pm 0.04$ & 0.960 & \\
\hline Neutrophil/lymphocyte ratio & $0.29 \pm 0.16$ & 0.072 & \\
\hline Eosinophils $\times 10^{3} / \mathrm{mm}^{3}$ & $-0.61 \pm 0.19$ & 0.002 & \\
\hline Plateletcrit, \% & $0.04 \pm 0.02$ & 0.016 & \\
\hline IL4 & $0.03 \pm 0.02$ & 0.144 & \\
\hline Constant & $-0.29 \pm 1.23$ & 0.813 & \\
\hline
\end{tabular}

${ }^{1}$ Variables that were explored but did not enter the pregnancy model $(P>0.15)$ : Gestational age, parity, IL4, IL10, IL12, IL17, TNFa

${ }^{2}$ Variables that were explored but did not enter the lactation model $(P>0.15)$ : Weeks postpartum, IL17

Table 4 Multiple linear and logistic regression models for Log CRP and elevated CRP in pregnant women

\begin{tabular}{|c|c|c|c|c|}
\hline CRP $(\mathrm{nmol} / \mathrm{L})$ in pregnant women ${ }^{1}$ & Coefficient $\pm S E$ & $P$ & $95 \% \mathrm{Cl}$ & Overall Model \\
\hline Wood smoke, h/d & $0.15 \pm 0.07$ & 0.032 & $0.01,0.30$ & \multirow{10}{*}{$\begin{array}{l}n=116 \\
F_{9,106}=3.99 \\
P=0.0002 \\
\text { Adj. } R^{2}=0.189 \\
V I F=1.52\end{array}$} \\
\hline Caries, presence & $0.66 \pm 0.26$ & 0.012 & $0.15,1.12$ & \\
\hline Lactobacillus, score & $-0.27 \pm 0.11$ & 0.020 & $-0.5,-0.04$ & \\
\hline Bacteroides/Gardnerella, score & $-0.35 \pm 0.14$ & 0.019 & $-0.64,-0.06$ & \\
\hline Mobiluncus, score & $0.20 \pm 0.10$ & 0.059 & $-0.008,0.42$ & \\
\hline Ascaris, presence & $-0.73 \pm 0.23$ & 0.002 & $-1.20,-0.27$ & \\
\hline Hookworm, presence & $0.56 \pm 0.22$ & 0.014 & $0.11,1.02$ & \\
\hline Trichuris, presence & $-0.57 \pm 0.33$ & 0.092 & $-1.24,0.09$ & \\
\hline Vitamin $A<1.05 \mu \mathrm{mol} / \mathrm{L}$ & $0.34 \pm 0.22$ & 0.122 & $-0.09,0.78$ & \\
\hline Constant & $1.55 \pm 0.06$ & 0.019 & $0.26,2.85$ & \\
\hline Elevated CRP in pregnant women ${ }^{2}$ & $O R \pm S E$ & $P$ & $95 \% \mathrm{Cl}$ & Overall model \\
\hline Gestational age & $0.92 \pm 0.03$ & 0.022 & $0.87,0.98$ & \multirow{8}{*}{$\begin{array}{l}n=116 \\
P=0.0006 \\
\text { Pseudo } R^{2}=0.243 \\
\text { VIF }=1.09\end{array}$} \\
\hline Wood smoke, h/d & $1.50 \pm 0.29$ & 0.034 & $1.03,2.19$ & \\
\hline Caries, presence & $3.86 \pm 2.46$ & 0.034 & $1.10,13.4$ & \\
\hline Vaginal yeast, score & $0.36 \pm 0.18$ & 0.050 & $0.13,0.99$ & \\
\hline Diplococcal infection, score & $2.04 \pm 0.53$ & 0.007 & $1.22,3.42$ & \\
\hline Folic acid $<10 \mathrm{nmol} / \mathrm{L}$ & $3.53 \pm 2.34$ & 0.057 & $0.96,12.9$ & \\
\hline Vitamin $A<1.05 \mu \mathrm{mol} / \mathrm{L}$ & $2.45 \pm 1.43$ & 0.124 & $0.78,7.72$ & \\
\hline Vitamin $\mathrm{D}<50 \mathrm{nmol} / \mathrm{L}$ & $2.74 \pm 1.91$ & 0.148 & $0.69,10.70$ & \\
\hline
\end{tabular}

${ }^{1}$ Variables that were explored but did not enter the linear regression model for CRP (nmol/L) in pregnancy $(P>0.15)$ : Gestational age, parity, BMI $\left(\mathrm{kg} / \mathrm{m}^{2}\right)$, fieldwork (h/d), presence of scabies and AB/UTI, score of trichomoniasis, vaginal yeast and diplococcal infection, folic acid $<10 \mathrm{nmol} / \mathrm{L}$, vitamin $B_{12}<150 \mathrm{pmol} / \mathrm{L}$, vitamin $A>1.5 \mu \mathrm{mol} / \mathrm{L}$. Vitamin $\mathrm{D}<50 \mathrm{nmol} / \mathrm{L}$

${ }^{2}$ Variables that were explored but did not enter the logistic regression model for elevated CRP ( $>28.50 \mathrm{nmol} / \mathrm{L},>193.34 \mathrm{nmol} / \mathrm{L}$ and $>77.14 \mathrm{nmol} / \mathrm{L}$ in the first, second and third trimesters, respectively [20]) in pregnancy $(P>0.15)$ : Parity, BMI $\left(\mathrm{kg} / \mathrm{m}^{2}\right)$, fieldwork (h/d), presence of scabies, AB/UTI, Ascaris, hookworm, Trichuris, score of Lactobacillus, Bacteroides/Gardnerella, Mobiluncus, trichomoniasis, vitamin $B_{12}<150 \mathrm{pmol} / \mathrm{L}$, vitamin A $>44.3 \mu \mathrm{mol} / \mathrm{L}$ 
Table 5 Multiple linear and logistic regression models for Log CRP and elevated CRP in lactating women

\begin{tabular}{|c|c|c|c|c|}
\hline CRP (nmol/L) in lactating women ${ }^{1}$ & Coefficient \pm SE & $P$ & $95 \% \mathrm{Cl}$ & Overall model \\
\hline Parity & $-0.17 \pm 0.06$ & 0.006 & $-0.29,-0.05$ & \multirow{9}{*}{$\begin{array}{l}n=78 \\
F_{8,69}=4.11 \\
P=0.0005 \\
\text { Adj. } R^{2}=0.244 \\
\text { VIF }=1.18\end{array}$} \\
\hline Fieldwork, h/d & $0.08 \pm 0.05$ & 0.119 & $-0.02,0.19$ & \\
\hline Eosinophils, number & $-0.48 \pm 0.20$ & 0.019 & $-0.88,-0.08$ & \\
\hline Caries, presence & $-0.61 \pm 0.34$ & 0.080 & $-1.30,0.07$ & \\
\hline Mobiluncus, score & $-0.31 \pm 0.13$ & 0.018 & $-0.57,-0.05$ & \\
\hline Folic acid $<10.0 \mathrm{nmol} / \mathrm{L}$ & $0.64 \pm 0.29$ & 0.033 & $0.05,1.23$ & \\
\hline Vitamin $A<1.05 \mu \mathrm{mol} / \mathrm{L}$ & $-0.73 \pm 0.38$ & 0.061 & $-1.50,0.03$ & \\
\hline Vitamin $A>1.50 \mu \mathrm{mol} / \mathrm{L}$ & $0.54 \pm 0.31$ & 0.085 & $-0.07,1.16$ & \\
\hline Constant & $3.57 \pm 0.50$ & $<0.0001$ & $2.56,4.57$ & \\
\hline Elevated CRP in lactating women ${ }^{2}$ & $O R \pm S E$ & $P$ & $95 \% \mathrm{Cl}$ & \\
\hline Parity & $0.53 \pm 0.12$ & 0.007 & $0.34,0.84$ & \multirow{5}{*}{$\begin{array}{l}n=78 \\
P=0.001 \\
\text { Pseudo } R^{2}=0.243 \\
\text { VIF }=1.08\end{array}$} \\
\hline BMI & $1.31 \pm 0.16$ & 0.029 & $1.02,1.66$ & \\
\hline Mobiluncus, score & $0.51 \pm 0.18$ & 0.066 & $0.25,1.04$ & \\
\hline Eosinophils, number & $0.24 \pm 0.16$ & 0.031 & $0.06,0.88$ & \\
\hline Trichomoniasis, score & $2.52 \pm 0.97$ & 0.016 & $1.18,5.36$ & \\
\hline
\end{tabular}

${ }^{1}$ Variables that were explored but did not enter the linear regression model for CRP (nmol/L) in lactation $(P>0.15):$ Weeks post-partum, BMI (kg/m $\left.{ }^{2}\right)$, wood smoke $(\mathrm{h} / \mathrm{d})$, presence of caries, score of vaginal Lactobacillus, Bactaroides/Gardnerella, T.vaginalis, yeast and diplococcal infection, vitamin $\mathrm{B}_{12}<150 \mathrm{pmol} / \mathrm{L}$, vitamin $\mathrm{D}<50 \mathrm{nmol} / \mathrm{L}$

${ }^{2}$ Variables that were explored but did not enter the logistic regression model for elevated CRP in lactation $(P>0.15)$ : Weeks post-partum, wood smoke exposure $(\mathrm{h} / \mathrm{d})$, fieldwork (h/d) presence of caries, score of vaginal Lactobacillus, Bacteroides/Gardnerella, Mobiluncus, yeast and diplcoccal infection, folic acid $<10 \mathrm{nmol} / \mathrm{L}$, vitamin $B_{12}<150 \mathrm{pmol} / \mathrm{L}$, vitamin $A<1.05 \mu \mathrm{mol} / \mathrm{L}$, vitamin $A>1.5 \mu \mathrm{mol} / \mathrm{L}$, vitamin $\mathrm{D}<50 \mathrm{nmol} / \mathrm{L}$

women with vaginal trichomoniasis [64]. It is also consistent with a mouse study that demonstrated signs of systemic inflammation associated with trichomoniasis [65].

One striking observation was that several vaginal bacteria were associated with lower, not higher CRP. The negative relationship between Lactobacillus and CRP in pregnancy is consistent with the observation that Lactobacillus dominates the vaginal flora in healthy women [66] and that many species of Lactobacillus are considered to be protective [67]. It is also consistent with the lower amount of Lactobacillus but higher CRP in pregnant compared with non-pregnant women in the US [68]. In addition, however, the typical pathogenic bacteria associated with BV, Bacterioides/Gardnerella and Mobiluncus [69], were also associated with lower CRP in pregnancy and lactation, respectively. As BV has been linked with inflammation during pregnancy [70, 71], we would have expected both Bacteriodes/Gardnerella and Mobiluncus to be associated with higher CRP but they were not. Together, these contrasting findings show that the vaginal tract has organisms that both increase and decrease CRP and is supported by a recent study showing women with BV and adverse pregnancy outcomes had different vaginal microbiota profiles compared to women with BV and no adverse pregnancy outcomes [71], indicating different host-parasite adaptations depending the type of vaginal microorganisms. This requires further investigation.

We were also intrigued that Ascaris was negatively associated with CRP whereas hookworm was positively associated with CRP in pregnancy. There is considerable evidence of the anti-inflammatory effect of Ascaris based on the in vitro suppressive effects of Ascaris suum-derived protein (PAS-1) on pro-inflammatory cytokine production [72], the down-regulation by low intensity Ascaris infection of the IL6 response to intestinal giardiasis [73], the antiinflammatory effect of Ascaris antigen on cytokine production by peripheral mononuclear cells from children when co-incubated with allergens [74], and the consistent protective effect of Ascaris against allergic sensitization found in a meta-analysis [75]. However, to our knowledge, this is the first report of a negative association of CRP with Ascaris during pregnancy. Also, the possibility that this antiinflammatory influence would reduce CRP in the presence of multiple infections and vitamin deficiencies has not been previously considered. This may have important public health implications during pregnancy given the health risks of pathologies often associated with inflammation.

There are two reasons why we would have also expected a negative association of hookworm with CRP. First, secretory products released by adult hookworms during feeding can down-regulate the inflammatory response in humans by suppressing TNFo secretion [76]. Second, although experimental hookworm infection in a human volunteer showed a transient increase in CRP as well as pro-inflammatory (IFNY) and T helper 2 (Th2) cytokines (IL5, IL13) soon after infection, this response was dampened once adult worms had reached the intestine and started shedding eggs [77]. It is unlikely that hookworm 
was a transient infection in women in our study, as the prevalence based on egg counts was over $50 \%$, indicating ongoing transmission [42]. The observed positive association between CRP and presence of hookworm in pregnancy may be explained by different degrees of tissue damage caused by the adult worms. In contrast to the noninvasive manner by which adult Ascaris worms feed [78], hookworm adults invade the mucosa and submucosa of the small intestine where the release of hydrolases and mechanical injury associated with feeding results in considerable tissue damage [79]. An additional justification for the different response of CRP between hookworm and Ascaris in pregnancy is explained by the capacity of the adult hookworm Necator americanus to produce proteases that specifically cleave the eosinophil chemoattractant eotaxin [80] whereas Ascaris induces higher transcription levels of eotaxin at least in pigs [81].

In this population where wood is used as fuel for cooking, increased hours of wood smoke exposure during pregnancy increased the odds of elevated CRP. Studies from India have reported that wood fuel use is associated with low birth weight [82], more frequent stillbirth and increased risk of preterm delivery [83], outcomes that are in turn associated with elevated CRP $[84,85]$. To our knowledge, this is the first report of an association between biofuel exposure and inflammation during pregnancy, although the finding is consistent with a study of women living in rural India that found increased serum CRP concentration in those exposed to wood smoke [12].

\section{Strengths and limitations}

This cross sectional screening of indigenous pregnant and lactating women in a remote outpatient setting allowed us to collect data on biomarkers of inflammation, infection and nutritional status and to associate these with CRP concentration during the three trimesters of pregnancy and 6 months postpartum. Nevertheless, we acknowledge the following limitations. The cross-sectional design precluded us from monitoring CRP over time and from relating CRP to pregnancy outcomes. The results of our multiple logistic regression models for trimester-specific elevations in CRP in pregnancy may need to be viewed with caution because of the lack of a consensus on trimester-specific cut-offs for CRP [85]. We were unable to explicitly consider intestinal nematodes in our regression models during lactation due to the high proportion of women who did not provide a faecal sample.

\section{Conclusions}

Both within the intestine and within the vaginal tract, some organisms raised and others lowered systemic CRP. This highlights the complexity of the associations of pathogens and CRP, and raises questions about how to interpret CRP in settings with multiple infections. It is possible that treatment of ascariasis may inadvertently increase CRP and that the treatment of BV may lead to the opportunistic growth of concurrent/more aggressive microorganisms and to an elevation in CRP, which could adversely affect pregnancy outcomes. Further, folic acid deficiency may play an under recognized role in leading to increased CRP concentrations in lactating women, in which case it might be recommended that folic acid supplementation be extended beyond 3 mo postpartum. Finally, consideration should be given to reducing exposure to indoor wood smoke particularly during pregnancy, given its role in increasing CRP.

\section{Additional file}

Additional file 1: Multilingual abstracts in the six official working languages of the United Nations. (PDF $829 \mathrm{~kb}$ )

\section{Abbreviations}

AB/UTI: Asymptomatic bacteriuria/urinary tract infection; BMI: Body mass index; BV: Bacterial vaginosis; CRP: C-reactive protein; HIV: Human immunodeficiency virus; IL: Interleukin; INDICASAT: Institute of Scientific Research and High Technology Services (Panama); IQR: Interquartile range; MPV: Mean platelet volume; NLR: Neutrophil/Lymphocyte ratio; PDW: Platelet distribution width; SENACYT: Secretaría Nacional de Ciencia, Tecnología e Innovación; Th2: Lymphocyte T helpers 2; VIF: Variance inflation factor; WBC: White blood cells; WHO: World Health Organization

\section{Acknowledgements}

The authors would like to acknowledge the clinical support of physicians and nurses of the "Comarca Ngäbe-Bugle" Health Region and the "Hospital General del Oriente Chiricano" in San Félix, Panama; the laboratory technicians and assistants at laboratories of "San Félix" Hospital, the Gorgas Commemoratory Institute, and INDICASAT for the processing biological samples; Z. Zambo and B. Williams for assisting with laboratory analyses of cytokines, and folic acid and vitamin $B_{12}$ respectively. Special acknowledgments are extended to community health workers, traditional midwives, indigenous authorities, "Virgen del Camino" Foundation in San Félix and to all women who participated in the study.

Funding

Panamanian "Secretaría Nacional de Ciencia, Tecnología e Innovación" (SENACYT) COL08-009 and McGill Vitamin Fund.

Availability of data and materials

The datasets analysed during the current study are not publicly available due to participant confidentially.

\section{Authors' contributions}

DGF, EM, MES and KGK were involved in the study conception, design, analysis and interpretation of data, drafting and critical revision of the manuscript. DGF, ECP, DR and OTS coordinated fieldwork and data collection. EM coordinated official relationships with SENACYT, the Panamanian funding agency, and INDICASAT for the processing of samples for vitamin A determination. KGK coordinated other vitamin processing with National reference laboratories in Quebec. All authors read and approved the final manuscript.

Competing interests

The authors declare that they have no competing interests.

Consent for publication

Not applicable. 


\section{Ethics approval and consent to participate}

Ethical approval was obtained from Institutional Review Board of McGill University in Canada (IRB Study Number A03-M25-08B), the Gorgas Memorial Institute Ethics Board in Panama, the Panamanian Ministry of Health, provincial and local health authorities, and indigenous authorities. Pregnant and lactating women who agreed to participate were recruited from among those seeking routine follow-up at rural Health Centers that covered the indigenous Ngäbe population, in Chiriquí province, Panama. Fully informed consent was obtained from all participants.

\section{Author details}

${ }^{1}$ School of Dietetics and Human Nutrition, Macdonald Campus of McGill University, 21,111 Lakeshore Road, Ste-Anne-de-Bellevue, QC H9X 3V9, Canada. ${ }^{2}$ Department of Nutritional Health, Ministry of Health, Ancón, Panama City, Panama. " "Comarca Ngäbe-Buglé" Health Region, Ministry of Health, San Félix, Chiriquí Province, Panama. "Panamá Norte" Health Region, Ministry of Health, Las Cumbres Square, Transithmian Highway, Panama City, Panama. ${ }^{5}$ Department of Biochemistry, University of Panama, Simón Bolivar Avenue (Transithmian Highway), Panama City, Panama. ${ }^{6}$ Department of Biochemistry, University of Panama, Manuel Espinoza Batista and Jose De Fabrega Avenues, Panama City, Panama. Institute of Parasitology and Centre for Host-Parasite Interactions, Macdonald Campus of McGill University, 21,111 Lakeshore Road, Ste-Anne-de-Bellevue, QC H9X 3 V9, Canada. ${ }^{8}$ School of Dietetics and Human Nutrition and Centre for Host-Parasite Interactions, Macdonald Campus, McGill University, 21,111 Lakeshore Road, Ste-Anne-de-Bellevue, QC H9X 3 V9, Canada.

\section{Received: 18 August 2016 Accepted: 17 April 2017} Published online: 02 June 2017

\section{References}

1. Eklund CM. Proinflammatory cytokines in CRP baseline regulation. Adv Clin Chem. 2009:48:111-36.

2. Pfafflin A, Schleicher E. Inflammation markers in point-of-care testing (POCT). Anal Bioanal Chem. 2009;393(5):1473-80

3. Thiele JR, Zeller J, Bannasch H, Stark GB, Peter K, Eisenhardt SU. Targeting $\mathrm{C}$-reactive protein in inflammatory disease by preventing conformational changes. Mediators Inflamm. 2015;2015:372432.

4. Bolia R, Srivastava A, Marak R, Yachha SK, Poddar U. Role of procalcitonin and $\mathrm{C}$-reactive protein as biomarkers of infection in children with liver disease. J Pediatr Gastroenterol Nutr. 2016;63(4):406-11. 2016/03/05.

5. Kraszewska-Glomba B, Szymanska-Toczek Z, Szenborn L. Procalcitonin and $C$-reactive protein-based decision tree model for distinguishing PFAPA flares from acute infections. Bosn J Basic Med Sci. 2016;16(2):157-61.

6. Lubell Y, Althaus T, Blacksell SD, Paris DH, Mayxay M, Pan-Ngum W, et al. Modelling the impact and cost-effectiveness of biomarker tests as compared with pathogen-specific diagnostics in the management of undifferentiated fever in remote tropical settings. PLoS One. 2016;11(3):e0152420.

7. Sullivan ZA, Wong EB, Ndung'u T, Kasprowicz VO, Bishai WR. Latent and active tuberculosis infection increase immune activation in individuals co-infected with HIV. EBioMedicine. 2015;2(4):334-40.

8. de Souza AB, Okawa RT, Silva CO and Araujo MG. Short-term changes on C-reactive protein (CRP) levels after non-surgical periodontal treatment in systemically healthy individuals. Clin Oral Investig. 2016. [Epub ahead of print]

9. Calcada D, Vianello D, Giampieri E, Sala C, Castellani G, de Graaf A, et al. The role of low-grade inflammation and metabolic flexibility in aging and nutritional modulation thereof: A systems biology approach. Mech Ageing Dev. 2014;136-137:138-47

10. Kuzawa CW, Adair LS, Borja J, McDade TW. C-reactive protein by pregnancy and lactational status among Filipino young adult women. Am J Hum Biol. 2013;25(1):131-4.

11. de Oliveira LC, Franco-Sena AB, Rebelo F, Farias DR, Lepsch J, Lima Nda S, et al. Factors associated with maternal serum C-reactive protein throughout pregnancy: A longitudinal study in women of Rio de Janeiro, Brazil. Nutrition. 2015;31(9):1103-8.

12. Dutta A, Ray MR, Banerjee A. Systemic inflammatory changes and increased oxidative stress in rural Indian women cooking with biomass fuels. Toxicol Appl Pharmacol. 2012;261(3):255-62.
13. Caravedo MA, Herrera PM, Mongilardi N, de Ferrari A, Davila-Roman VG, Gilman RH, et al. Chronic exposure to biomass fuel smoke and markers of endothelial inflammation. Indoor Air. 2016;26(5):768-75.

14. Hawkins M, Braun B, Marcus BH, Stanek 3rd E, Markenson G, Chasan-Taber L. The impact of an exercise intervention on C-reactive protein during pregnancy: $\mathrm{A}$ randomized controlled trial. BMC Pregnancy Childbirth. 2015;15:139.

15. Wang Y, Cupul-Uicab LA, Rogan WJ, Eggesbo M, Travlos G, Wilson R, et al. Recreational exercise before and during pregnancy in relation to plasma C-reactive protein concentrations in pregnant women. J Phys Act Health. 2015;12(6):770-5.

16. Belo L, Santos-Silva A, Rocha S, Caslake M, Cooney J, Pereira-Leite L, et al. Fluctuations in C-reactive protein concentration and neutrophil activation during normal human pregnancy. Eur J Obstet Gynecol Reprod Biol. 2005;123(1):46-51.

17. Cicarelli LM, Perroni AG, Zugaib M, de Albuquerque PB, Campa A. Maternal and cord blood levels of serum amyloid A, C-reactive protein, tumor necrosis factor-alpha, interleukin-1Beta, and interleukin-8 during and after delivery. Mediators Inflamm. 2005;2005(2):96-100.

18. Pringle KG, Rae K, Weatherall L, Hall S, Burns C, Smith R, et al. Effects of maternal inflammation and exposure to cigarette smoke on birth weight and delivery of preterm babies in a cohort of indigenous Australian women. Front Immunol. 2015;6:89.

19. Cunningham FG. Laboratory values in normal pregnancy. In: J.T. Queenan, Hobbins JC, and Spong CY, editors. Protocols for high-risk pregnancies: An evidence-based approach. United Kingdom: Blackwell Science Ltd.; 2010. p. $578-95$.

20. Abbassi-Ghanavati M, Greer LG, Cunningham FG. Pregnancy and laboratory studies: A reference table for clinicians. Obstet Gynecol. 2009;114(6):1326-31.

21. Azizia MM, Irvine LM, Coker M, Sanusi FA. The role of C-reactive protein in modern obstetric and gynecological practice. Acta Obstet Gynecol Scand. 2006;85(4):394-401.

22. Gebreselassie SG, Gase FE, Deressa MU. Prevalence and correlates of prenatal vitamin A deficiency in rural Sidama, Southern Ethiopia. J Health Popul Nutr. 2013;31(2):185-94.

23. Silva MC, Furlanetto TW. Does serum 25-hydroxyvitamin D decrease during acute-phase response? A systematic review. Nutr Res. 2015;35(2):91-6.

24. Kim H, Hwang JY, Ha EH, Park $\mathrm{H}, \mathrm{Ha}$ M, Lee SJ, et al. Association of maternal folate nutrition and serum $\mathrm{C}$-reactive protein concentrations with gestational age at delivery. Eur J Clin Nutr. 2011;65(3):350-6.

25. Haynes BM, Pfeiffer CM, Sternberg MR, Schleicher RL. Selected physiologic variables are weakly to moderately associated with 29 biomarkers of diet and nutrition, NHANES 2003-2006. J Nutr. 2013;143(6):1001S-10S.

26. Abbenhardt C, Miller JW, Song X, Brown EC, Cheng TY, Wener MH, et al. Biomarkers of one-carbon metabolism are associated with biomarkers of inflammation in women. J Nutr. 2014;144(5):714-21.

27. Han YS, Ha EH, Park HS, Kim YJ, Lee SS. Relationships between pregnancy outcomes, biochemical markers and pre-pregnancy body mass index. Int J Obes (Lond). 2011;35(4):570-7.

28. Friis CM, Paasche Roland MC, Godang K, Ueland T, Tanbo T, Bollerslev J, et al. Adiposity-related inflammation: Effects of pregnancy. Obesity (Silver Spring). 2013;21(1):E124-30.

29. Kaestel P, Martinussen T, Aaby P, Michaelsen KF, Friis H. Serum retinol is associated with stage of pregnancy and the acute phase response in pregnant women in Guinea-Bissau. J Nutr. 2012;142(5):942-7.

30. Dancheck B, Nussenblatt V, Ricks MO, Kumwenda N, Neville MC, Moncrief DT, et al. Breast milk retinol concentrations are not associated with systemic inflammation among breast-feeding women in Malawi. J Nutr. 2005;135(2):223-6.

31. Asemi Z, Hashemi T, Karamali M, Samimi M, Esmaillzadeh A. Effects of vitamin D supplementation on glucose metabolism, lipid concentrations, inflammation, and oxidative stress in gestational diabetes: A double-blind randomized controlled clinical trial. Am J Clin Nutr. 2013;98(6):1425-32.

32. Bobbitt KR, Peters RM, Li J, Rao SD, Woodcroft KJ, Cassidy-Bushrow AE. Early pregnancy vitamin $D$ and patterns of antenatal inflammation in African-American women. J Reprod Immunol. 2015;107:52-8.

33. Hindle LJ, Gitau R, Filteau SM, Newens KJ, Osrin D, Costello AM, et al. Effect of multiple micronutrient supplementation during pregnancy on inflammatory markers in Nepalese women. Am J Clin Nutr. 2006;84(5):1086-92. 
34. Du Clos TW. Pentraxins: Structure, function, and role in inflammation. ISRN Inflamm. 2013;2013:379040.

35. Bello S, Minchole E, Fandos S, Lasierra AB, Ruiz MA, Simon AL, et al. Inflammatory response in mixed viral-bacterial community-acquired pneumonia. BMC Pulm Med. 2014;14:123.

36. Drain PK, Mayeza L, Bartman P, Hurtado R, Moodley P, Varghese S, et al. Diagnostic accuracy and clinical role of rapid C-reactive protein testing in HIV-infected individuals with presumed tuberculosis in South Africa. Int J Tuberc Lung Dis. 2014;18(1):20-6.

37. Epelboin L, Hanf M, Dussart P, Ouar-Epelboin S, Djossou F, Nacher M, et al. Is dengue and malaria co-infection more severe than single infections? A retrospective matched-pair study in French Guiana. Malar J. 2012;11:142.

38. Maizels RM. Parasitic helminth infections and the control of human allergic and autoimmune disorders. Clin Microbiol Infect. 2016;22(6):481-6.

39. Ersoy AO, Ozler S, Oztas E, Ersoy E, Kirbas A, Danisman N. The association between placenta previa and leukocyte and platelet indices - a case control study. Ginekol Pol. 2016;87(5):367-71.

40. Serin S, Avci F, Ercan O, Kostu B, Bakacak M, Kiran H. Is neutrophil/ lymphocyte ratio a useful marker to predict the severity of pre-eclampsia? Pregnancy Hypertens. 2016;6(1):22-5.

41. Sahbaz A, Cicekler H, Aynioglu O, Isik H, Ozmen U. Comparison of the predictive value of plateletcrit with various other blood parameters in gestational diabetes development. J Obstet Gynaecol. 2016;36(5):589-93.

42. Gonzalez-Fernandez D, Koski KG, Sinisterra OT, Del Carmen Pons E, Murillo E, Scott ME. Interactions among urogenital, intestinal, skin, and oral infections in pregnant and lactating Panamanian Ngäbe women: A neglected public health challenge. Am J Trop Med Hyg. 2015;92(6):1100-10.

43. Kuamri A, Goswami S, Mukherjee P. Comparative study of various methods of fetal weight estimation in term pregnancy. South Asian Feder Obst Gynae. 2013;5(1):22-5.

44. Fescina R H, De Mucio B, Martínez G, Alemán A, Sosa C, Mainero L, et al. Monitoring fetal growth: Self-instruction manual. In: Scientific Publication CLAP/WR 1586.02. 2011. http://www.paho.org/Clap/index.php?option=com docman\&task=doc_details\&gid=241\&tmpl=component\&ltemid=. Accessed 20 Apr 2017.

45. WHO. BMI classification. Global Database on Body Mass Index, 2012. http://apps.who.int/bmi/index.jsp?introPage=intro_3.html. Accessed 20 Apr 2017.

46. Nugent RP, Krohn MA, Hillier SL. Reliability of diagnosing bacterial vaginosis is improved by a standardized method of Gram stain interpretation. J Clin Microbiol. 1991;29(2):297-301.

47. de Benoist $\mathrm{B}$. Conclusions of a $\mathrm{WHO}$ technical consultation on folate and vitamin B12 deficiencies. Food Nutr Bull. 2008:29(2 Suppl):S238-44.

48. Gundersen $T E$, Lundanes E, Blomhoff R. Quantitative high-performance liquid chromatographic determination of retinoids in human serum using on-line solid-phase extraction and column switching. Determination of 9-cis-retinoic acid, 13-cis-retinoic acid, all-trans-retinoic acid, 4-oxo-all-transretinoicacid and 4-oxo-13-cis-retinoic acid. J Chromatogr B Biomed Sci Appl. 1997:69(1):43-58.

49. WHO. Global prevalence of vitamin A deficiency in populations at risk 1995-2005. Micronutrient Database, 2009. http:/www.who.int/vmnis/ database/vitamina///en/. Accessed 20 Apr 2017.

50. Duerbeck NB, Dowling DD. Vitamin A: Too much of a good thing? Obstet Gynecol Surv. 2012;67(2):122-8.

51. Balvers MG, Brouwer-Brolsma EM, Endenburg S, de Groot LC, Kok FJ, Gunnewiek JK. Recommended intakes of vitamin D to optimise health, associated circulating 25-hydroxyvitamin D concentrations, and dosing regimens to treat deficiency: Workshop report and overview of current literature. J Nutr Sci. 2015;4:e23.

52. Gasparyan AY, Ayvazyan L, Mikhailidis DP, Kitas GD. Mean platelet volume: A link between thrombosis and inflammation? Curr Pharm Des. 2011;17(1):47-58.

53. Lowsby R, Gomes C, Jarman I, Lisboa P, Nee PA, Vardhan M, et al. Neutrophil to lymphocyte count ratio as an early indicator of blood stream infection in the emergency department. Emerg Med J. 2015;32(7):531-4.

54. Kim MA, Lee YS, Seo K. Assessment of predictive markers for placental inflammatory response in preterm births. PLoS One. 2014;9(10):e107880.

55. van der Poll $\mathrm{T}$, Herwald $H$. The coagulation system and its function in early immune defense. Thromb Haemost. 2014;112(4):640-8.

56. D'Souza C, Briggs C, Machin SJ. Platelets: The few, the young, and the active. Clin Lab Med. 2015;35(1):123-31.
57. Chen L, Grabowski KA, Xin JP, Coleman J, Huang Z, Espiritu B, et al. IL-4 induces differentiation and expansion of Th2 cytokine-producing eosinophils. J Immunol. 2004;172(4):2059-66.

58. Finkelman FD, Urban Jr JF. The other side of the coin: The protective role of the Th2 cytokines. J Allergy Clin Immunol. 2001;107(5):772-80.

59. Yazar FM, Bakacak M, Emre A, Urfalioglu A, Serin S, Cengiz E, et al. Predictive role of neutrophil-to-lymphocyte and platelet-to-lymphocyte ratios for diagnosis of acute appendicitis during pregnancy. Kaohsiung J Med Sci. 2015;31(11):591-6.

60. Fujita M, Brindle E, Lo YJ, Castro P, Cameroamortegui F. Nutrient intakes associated with elevated serum $C$-reactive protein concentrations in normal to underweight breastfeeding women in northern Kenya. Am J Hum Biol. 2014;26(6):796-802.

61. Ko A, Kim H, Han CJ, Kim JM, Chung HW, Chang N. Association between high sensitivity C-reactive protein and dietary intake in Vietnamese young women. Nutr Res Pract. 2014;8(4):445-52.

62. Ruma M, Boggess K, Moss K, Jared H, Murtha A, Beck J, et al. Maternal periodontal disease, systemic inflammation, and risk for preeclampsia. Am J Obstet Gynecol. 2008;198(4):389 e1-5.

63. Sharma A, Astekar M, Metgud R, Soni A, Verma M, Patel S. A study of C-reactive protein, lipid metabolism and peripheral blood to identify a link between periodontitis and cardiovascular disease. Biotech Histochem. 2014;89(8):577-82.

64. Anderson BL, Cosentino LA, Simhan HN, Hillier SL. Systemic immune response to Trichomonas vaginalis infection during pregnancy. Sex Transm Dis. 2007;34(6):392-6.

65. Escario A, Gomez Barrio A, Simons Diez B, Escario JA. Immunohistochemical study of the vaginal inflammatory response in experimental trichomoniasis. Acta Trop. 2010;114(1):22-30.

66. Onderdonk AB, Delaney ML, Fichorova RN. The human microbiome during bacterial vaginosis. Clin Microbiol Rev. 2016;29(2):223-38.

67. Petrova MI, Lievens E, Malik S, Imholz N, Lebeer S. Lactobacillus species as biomarkers and agents that can promote various aspects of vaginal health. Front Physiol. 2015;6:81.

68. Anderson BL, Mendez-Figueroa H, Dahlke JD, Raker C, Hillier SL, Cu-Uvin S. Pregnancy-induced changes in immune protection of the genital tract: Defining normal. Am J Obstet Gynecol. 2013;208(4):321. e1-9.

69. Hainer BL, Gibson MV. Vaginitis. Am Fam Physician. 2011;83(7):807-15.

70. Goffinet F, Maillard F, Mihoubi N, Kayem G, Papiernik E, Cabrol D, et al. Bacterial vaginosis: Prevalence and predictive value for premature delivery and neonatal infection in women with preterm labour and intact membranes. Eur J Obstet Gynecol Reprod Biol. 2003;108(2):146-51. 2003/06/05.

71. Faure E, Faure K, Figeac M, Kipnis E, Grandjean T, Dubucquoi S, et al. Vaginal mucosal homeostatic response may determine pregnancy outcome in women with bacterial vaginosis: A pilot study. Medicine (Baltimore). 2016;95(5):e2668.

72. Antunes MF, Titz TO, Batista IF, Marques-Porto R, Oliveira CF, de Araujo CA, et al. Immunosuppressive PAS-1 is an excretory/secretory protein released by larval and adult worms of the ascarid nematode Ascaris suum. J Helminthol. 2014:89(3):367-74.

73. Hagel I, Cabrera M, Puccio F, Santaella C, Buvat E, Infante B, et al. Co-infection with Ascaris lumbricoides modulates protective immune responses against Giardia duodenalis in school Venezuelan rural children. Acta Trop. 2011;117(3):189-95.

74. Hegewald J, Gantin RG, Lechner CJ, Huang X, Agosssou A, Agbeko YF, et al. Cellular cytokine and chemokine responses to parasite antigens and fungus and mite allergens in children co-infected with helminthes and protozoa parasites. J Inflamm (Lond). 2015;12:5.

75. Feary J, Britton J, Leonardi-Bee J. Atopy and current intestinal parasite infection: A systematic review and meta-analysis. Allergy. 2011;66(4):569-78.

76. Geiger SM, Caldas IR, Mc Glone BE, Campi-Azevedo AC, De Oliveira LM, Brooker S, et al. Stage-specific immune responses in human Necator americanus infection. Parasite Immunol. 2007;29(7):347-58.

77. Wright $\mathrm{V}$, Bickle Q. Immune responses following experimental human hookworm infection. Clin Exp Immunol. 2005;142(2):398-403. 2005/10/20.

78. Lamberton PH, Jourdan PM. Human ascariasis: Diagnostics update. Curr Trop Med Rep. 2015;2(4):189-200.

79. Barakat $\mathrm{M}$, Ibrahim $\mathrm{N}$, Nasr A. In vivo endoscopic imaging of ancylostomiasis-induced gastrointestinal bleeding: Clinical and biological profiles. Am J Trop Med Hyg. 2012;87(4):701-5.

80. Culley FJ, Brown A, Conroy DM, Sabroe I, Pritchard DI, Williams TJ. Eotaxin is specifically cleaved by hookworm metalloproteases preventing its action in vitro and in vivo. J Immunol. 2000;165(11):6447-53. 
81. Masure D, Vlaminck J, Wang T, Chiers K, Van den Broeck W, Vercruysse J, et al. A role for eosinophils in the intestinal immunity against infective Ascaris suum larvae. PLoS Negl Trop Dis. 2013;7(3):e2138.

82. Kadam YR, Mimansa A, Chavan PV, Gore AD. Effect of prenatal exposure to kitchen fuel on birth weight. Indian J Community Med. 2013;38(4):212-6.

83. Wylie BJ, Singh MP, Coull BA, Quinn A, Yeboah-Antwi K, Sabin L, et al, Association between wood cooking fuel and maternal hypertension at delivery in central East India. Hypertens Pregnancy. Hypertens Pregnancy. 2015;34(3):355-68

84. Grgic G, Skokic F, Bogdanovic G. C-reactive protein as a biochemical marker of idiopathic preterm delivery. Med Arh. 2010;64(3):132-4.

85. Ernst GD, de Jonge LL, Hofman A, Lindemans J, Russcher H, Steegers EA, et al. C-reactive protein levels in early pregnancy, fetal growth patterns, and the risk for neonatal complications: The generation R study. Am J Obstet Gynecol. 2011;2(132):e1-12.

Submit your next manuscript to BioMed Central and we will help you at every step:

- We accept pre-submission inquiries

- Our selector tool helps you to find the most relevant journal

- We provide round the clock customer support

- Convenient online submission

- Thorough peer review

- Inclusion in PubMed and all major indexing services

- Maximum visibility for your research

Submit your manuscript at www.biomedcentral.com/submit
Biomed Central 